\title{
Short communication: Alterations in expression of gluconeogenic genes during heat stress and exogenous bovine somatotropin administration ${ }^{1}$
}

\author{
R. P. Rhoads, ${ }^{2}$ A. J. La Noce, J. B. Wheelock, and L. H. Baumgard ${ }^{3}$ \\ Department of Animal Sciences, The University of Arizona, Tucson 85721
}

\begin{abstract}
Study objectives were to evaluate hepatic gluconeogenic enzyme gene expression in recombinant bovine somatotropin (rbST)-treated lactating dairy cattle during heat stress (HS) or in thermal-neutral, pair-fed (PF) animals. Twenty-two multiparous (99 d in milk, $656 \mathrm{~kg}$ of BW) Holstein cows were subjected to 3 consecutive experimental periods (7 d each): (1) thermal neutral, (2) HS or PF, and (3) HS or PF with rbST (Posilac, administered on d 1 of period 3). Liver biopsies were obtained on the final day of each period. Heat stress conditions progressively decreased dry matter intake for the first 5 to $6 \mathrm{~d}$ during period 2 before stabilizing (a decrease of $6.15 \mathrm{~kg} ; 30 \%$ ) on d 6 and 7 , and feed intake remained stable and not different from period 2 during period 3. Cytosolic phosphoenolpyruvate carboxykinase mRNA abundance increased during PF, but was unaffected by HS or bST. Pyruvate carboxylase gene expression increased during $\mathrm{HS}$ and $\mathrm{PF}$, and administrating bST decreased pyruvate carboxylase mRNA abundance during both HS and PF. Insulin-like growth factor-I gene expression increased following bST administration during $\mathrm{HS}$ and $\mathrm{PF}$, confirming hepatic bST responsiveness. Exposure to HS leads to a change in hepatic gluconeogenic enzyme profile that appears to be dependent on plane of nutrition.
\end{abstract}

Key words: gluconeogenesis, heat stress, bovine somatotropin

\section{Short Communication}

Lactating heat-stressed (HS) dairy cows undergo dramatic changes in energy metabolism that negatively affect production, but likely improve the cows' heat tolerance (Rhoads et al., 2009, 2010; Wheelock et al.,

\footnotetext{
Received August 12, 2010.

Accepted November 16, 2010.

${ }^{1}$ This work was previously reported at the 2008 ADSA Annual Meeting (Wheelock et al., 2008). This project was supported by National Research Initiative Competitive Grant No. 2008-35206-18817 from the USDA National Institute of Food and Agriculture.

${ }^{2}$ Corresponding author: rhoadsr@email.arizona.edu

${ }^{3}$ Current address: Iowa State University, Ames 50011.
}

2010). Heat-related health issues and production losses cost the US dairy industry close to $\$ 1$ billion annually (St-Pierre et al., 2003). Although reduced nutrient intake contributes to decreased milk synthesis and metabolic changes, recent data indicate HS directly affects both parameters (Rhoads et al., 2009). For example, lactating HS cows dispose of glucose more readily and have increased basal and stimulated plasma insulin concentrations compared with thermal-neutral cohort animals on a similar plane of nutrition (Wheelock et al., 2010). In addition, HS cows do not appear to mobilize adipose tissue despite losing considerable BW (>40 kg) and entering a period of negative energy balance that would suggest otherwise (Shwartz et al., 2009; Rhoads et al., 2009; Wheelock et al., 2010). Taken together, these observations indicate that during HS, the lactating dairy cow is forced to increase reliance on glucose as a fuel source (ostensibly to remain euthermic), and glucose use for milk synthesis is deemphasized.

Ruminants obtain little to no glucose directly from dietary digestion; therefore, gluconeogenesis is vital to supplying extra-hepatic tissues with glucose. In the high-producing dairy cow, 60 to $85 \%$ of synthesized glucose is used in milk synthesis (Bauman and Vernon, 1993). Hepatic use of various precursors, such as propionate, AA, lactate, and glycerol, are shuttled through the gluconeogenic pathway in a coordinated manner by the rate-limiting enzymes: pyruvate carboxylase (PC) and phosphoenolpyruvate carboxykinase 1 (PCK). Malnutrition and altering physiological states, such as lactation initiation, increase the rate of hepatic gluconeogenesis (Bauman and Vernon, 1993; Greenfield et al., 2000; Velez and Donkin, 2005), indicating that glucose production is responsive to metabolic shifts and physiological cues. However, whether the altered energy metabolism during HS coincides with changes in hepatic gluconeogenesis capacity is unclear.

Bovine somatotropin is a metabolic modifier providing a homeorhetic adjustment that facilitates body reserve mobilization and enables glucose-sparing mechanisms to divert nutrient resources for milk synthesis (Bauman and Vernon, 1993). The ability of bST to alter hepatic function underlies a portion of the metabolic modifier role, an effect that varies according to physiological 
state, nutrition, and disease (Bauman and Vernon, 1993; Donaghy and Baxter, 1996). In well-managed situations, the enhanced milk synthesis following bST administration is thought to occur in part because of bST-dependent hepatic IGF-I production, and both milk and hepatic IGF-I responses fail during periods of severe negative energy balance (Bauman and Vernon, 1993). Gluconeogenesis is a second hepatic target for bST. Bauman and Vernon (1993) report that bST increases basal rates of hepatic gluconeogenesis and blocks the inhibitory action of insulin on this metabolic pathway. It is not entirely clear how endogenous somatotropin enhances hepatic gluconeogenesis as equivocal data have been generated regarding the effect of exogenous bST administration on mRNA abundance of key gluconeogenic enzymes (Pershing et al., 2002; Velez and Donkin, 2004).

The primary purpose of this study was to determine if or how HS regulates gluconeogenic gene expression and to determine if HS influences how bST modulates liver glucose production. Investigating the interactions between heat stress, bST, and hepatic gluconeogenesis will not only yield a clearer understanding of the underlying biology of how HS affects postabsorptive carbohydrate metabolism, but also may lead to useful applications within the dairy industry.

The animals and experimental design used in this study have been described previously (Wheelock et al., 2010). Briefly, 22 multiparous, lactating Holstein cows $(99.8 \pm 20.2$ DIM, $655.4 \pm 62.9 \mathrm{~kg} \mathrm{BW})$ were randomly assigned to 1 of 2 environmental treatments during 3 consecutive experimental periods $(\mathbf{P})$ consisting of (1) $7 \mathrm{~d}$ of thermal-neutral conditions and ad libitum feeding; (2) $7 \mathrm{~d}$ of either HS and ad libitum intake or pair feeding (PF) in thermal-neutral conditions; and (3) 7 $\mathrm{d}$ of either continual HS and ad libitum feed or PF in thermal-neutral conditions with rbST supplementation. Animals in the thermal-neutral control conditions (n $=12)$ were PF with HS animals $(\mathrm{n}=10)$ to eliminate confounding effects of dissimilar nutrient intake. Reductions in DMI were calculated daily as the percentage decrease from the average DMI in P1, and that percentage was applied to the PF thermal-neutral group, which was trailing the HS cows by $2 \mathrm{~d}$. No cows were receiving rbST before the start of the experiment. The rbST injections (Posilac, Monsanto, St. Louis, MO) were administered subcutaneously per label instructions to all animals on d 1 of P3. Animals were maintained in tiestall stanchions at the University of Arizona's William J. Parker Agricultural Research Complex, and all procedures were approved by the University of Arizona Institutional Animal Care and Use Committee.

During $\mathrm{P} 1$, all animals were housed in constant thermal-neutral conditions $\left(20^{\circ} \mathrm{C}, 20 \%\right.$ humidity with a 12-light, 12-h dark cycle). Starting on the first day of P2 and continuing until the last day of P3, cows assigned to the HS treatment experienced cyclical daily temperatures (in an attempt to mimic daily variation) ranging from $29.4^{\circ} \mathrm{C}$ to $38.9^{\circ} \mathrm{C}$ (constant $20 \%$ humidity and a 12-light, 12-h dark cycle). Cows in the PF group remained (during P2 and P3) in constant thermalneutral conditions as described for $\mathrm{P} 1$.

Liver tissue samples were collected from all animals on $\mathrm{d} 7$ of each period through percutaneous biopsy as described previously (Rhoads et al., 2004). In brief, a 12 -gauge biopsy trocar $(15 \mathrm{~cm}$ long with a $20-\mathrm{mm}$ notch; US Biopsy, Franklin, IN) was inserted between the 11th and 12th ribs to remove a small liver sample, and samples were snap frozen in liquid nitrogen and stored at $-80^{\circ} \mathrm{C}$ until analysis.

Total RNA was extracted with TRIzol reagent according to the manufacturer's protocol (Invitrogen, Carlsbad, CA) and was DNase treated (RNase-Free DNase set, Qiagen Inc., Valencia, CA) and purified by affinity chromatography (RNeasy, Qiagen Inc.) to remove potential genomic DNA contamination. The total RNA concentration was determined by absorbance at $260 \mathrm{~nm}$, and quality was verified by agarose gel electrophoresis. Total RNA was stored at $-80^{\circ} \mathrm{C}$ until gene expression analysis.

Gene expression analysis was performed using realtime PCR as described previously (Rhoads et al., 2010). Briefly, total RNA $(2 \mu \mathrm{g})$ was reverse transcribed using the SuperScript First Strand Synthesis System for reverse transcription PCR (Invitrogen). Primer sets for bovine PCK, PC, and IGF-I were designed using Primer Express Software (Applied Biosystems) based on published bovine nucleotide sequences (accession numbers AY145503, NM177946, and X15726, respectively). Ribosomal protein S9 gene expression served as the housekeeping or control gene (Rhoads et al., 2010). Reactions $(25 \mu \mathrm{L})$ were prepared according to manufacturer's instructions using the iQ SYBR Green Supermix (Bio-Rad Laboratories Inc., Hercules, CA), $100 \mathrm{n} M$ of each forward and reverse primer, and $10 \mathrm{ng}$ of cDNA. The PCR quantification of each sample was performed in triplicate and SYBR Green fluorescence was quantified with the iQ5 real-time PCR detection system (Bio-Rad Laboratories Inc.). Each assay plate contained negative controls and a standard curve (5 serial dilutions of a pool cDNA sample) to determine amplification efficiency of the respective primer pair. Each assay consisted of an initial stage $\left(95^{\circ} \mathrm{C}\right.$ for $\left.10 \mathrm{~min}\right)$ followed by $40 \mathrm{PCR}$ cycles, with each cycle consisting of 2 stages $\left(95^{\circ} \mathrm{C}\right.$ for $10 \mathrm{~s}$ and $60^{\circ} \mathrm{C}$ for $\left.1 \mathrm{~min}\right)$; a dissociation curve was included to verify the amplification of a single PCR product. Analyses of amplification plots were performed with the iQ5 Optical System software 


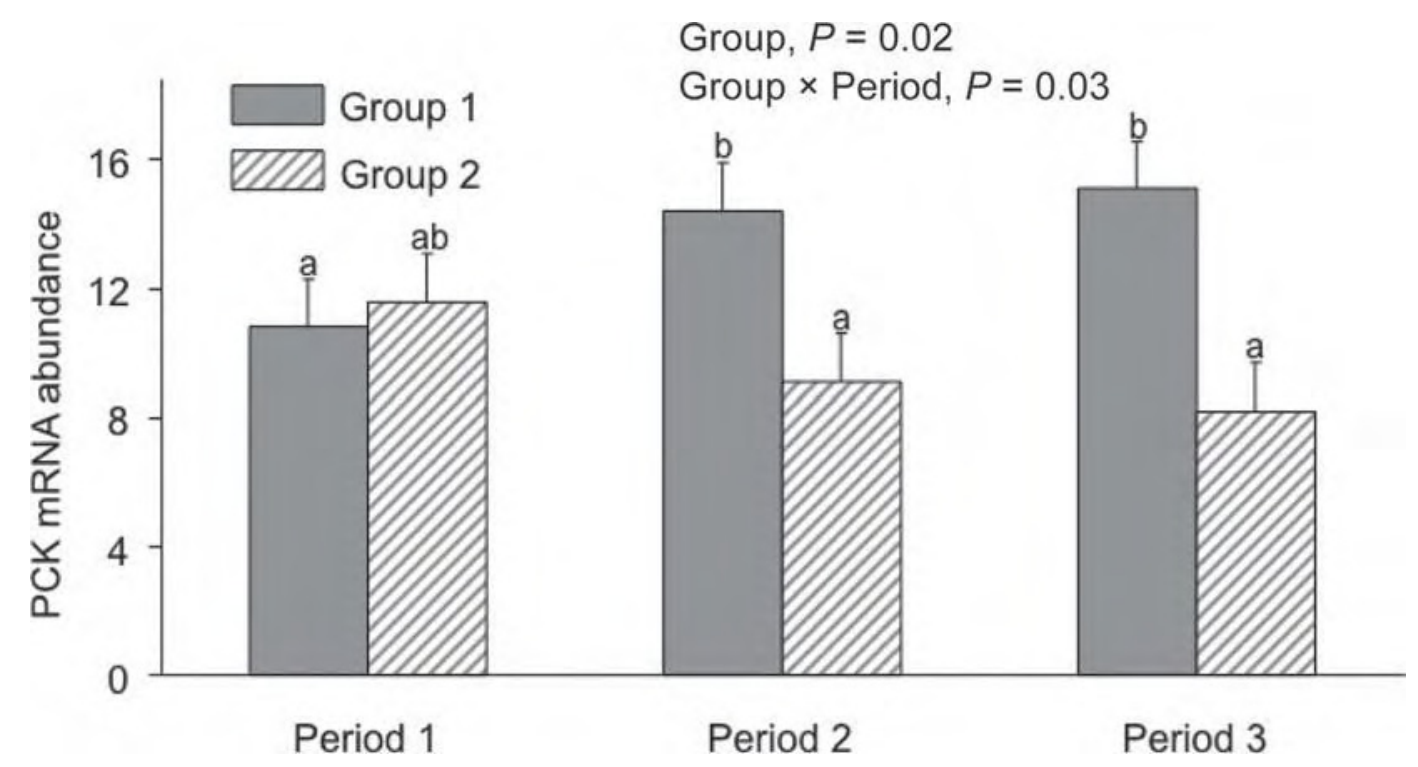

Figure 1. Effect of heat stress and plane of nutrition on bovine hepatic cytosolic phosphoenolpyruvate carboxykinase (PCK) gene expression. Cows were separated into 2 groups based on pair feeding (group 1) or heat stress (group 2) treatment and studied during environmental conditions consisting of 3 periods. During period 1, each group was housed in thermal-neutral conditions and given ad libitum access to feed. During period 2, group 1 was pair fed (based on group 2 intake in period 2) and maintained in thermal-neutral conditions, whereas group 2 cows were maintained in heat stress conditions. During period 3, each group remained in conditions as described in period 2, and recombinant bST was administered on $\mathrm{d} 1$ of period 3 . Different letters denote group $\times$ period interactions $(P<0.05)$.

(v. 2.0; Bio-Rad Laboratories, Inc.). The fold differences between the internal control sample and the samples of interest were calculated with the amplification efficiencies of each respective target gene (amplification efficiency taken to the power of the control $\mathrm{C}_{\mathrm{T}}$ minus the sample $\mathrm{C}_{\mathrm{T}}$ ).

Effects of group (PF or HS), period (1, 2, or 3), and their interaction were assessed as a completely randomized design using the PROC MIXED procedure of SAS (v. 9.1; SAS Inst. Inc., Cary, NC) and had cow as the random effect. Each animal's respective gene was analyzed using repeated measures with an autoregressive covariance structure and period as the repeated effect. An ad hoc analysis also was conducted to evaluate the effects of the environmental challenge (P2 or P3) alone; this model included the fixed and random effects as described in the original model. Data are reported as least squares means and were considered significant if $P<0.05$.

Upon high ambient temperature exposure, a nonsignificant 20\% reduction in the abundance of PCK mRNA was observed in HS cows, which remained unchanged following bST administration (Figure 1). In contrast, PCK gene expression increased 43 and $50 \%$ in PF cows during P2 (underfeeding) and P3 (following bST administration), respectively (group $\times$ period interaction, $P=0.03$; Figure 1). Compared with $\mathrm{P} 1$, both $\mathrm{PF}$ and HS cows during P2 had a similar increase $(51 \%$; $P<$
0.01) in PC mRNA abundance; this effect was reversed following bST administration (Figure 2). However, analysis from the truncated model (containing only P2 and P3) indicated PC mRNA abundance decreased only in HS cows during P3 $\left(19.3^{\mathrm{a}}, 17.8^{\mathrm{a}}, 17.3^{\mathrm{a}}\right.$, and $12.6^{\mathrm{b}}$ for PF and HS cows in P2 and P3, respectively).

Based on PC and PCK expression, it appeared that hepatic responsiveness to bST might have been lost during HS and PF. To determine if that was the case, we measured hepatic IGF-I mRNA abundance, a gene whose expression in liver is growth hormone dependent. During HS, bST treatment elicited a 2-fold induction of IGF-I mRNA abundance $(P<0.01$, Figure 3$)$. Similarly, administering bST to PF cows caused a 3-fold increase in IGF-I mRNA abundance $(P<0.01$, Figure 3). Neither HS nor PF (modest undernutrition) alone was sufficient to alter abundance of hepatic IGF-I gene expression.

Evidence indicates that lactating dairy cows experiencing HS may utilize glucose in peripheral tissues to a greater extent than cohort animals on a similar plane of nutrition in thermal-neutral conditions (Rhoads et al., 2009; Wheelock et al., 2010). Given the importance of hepatic gluconeogenesis to glucose supply in ruminants, we examined the possibility that HS may affect hepatic expression of gluconeogenic genes. Heat stress increased hepatic PC gene expression compared with P1; however, plane of nutrition may participate in this 


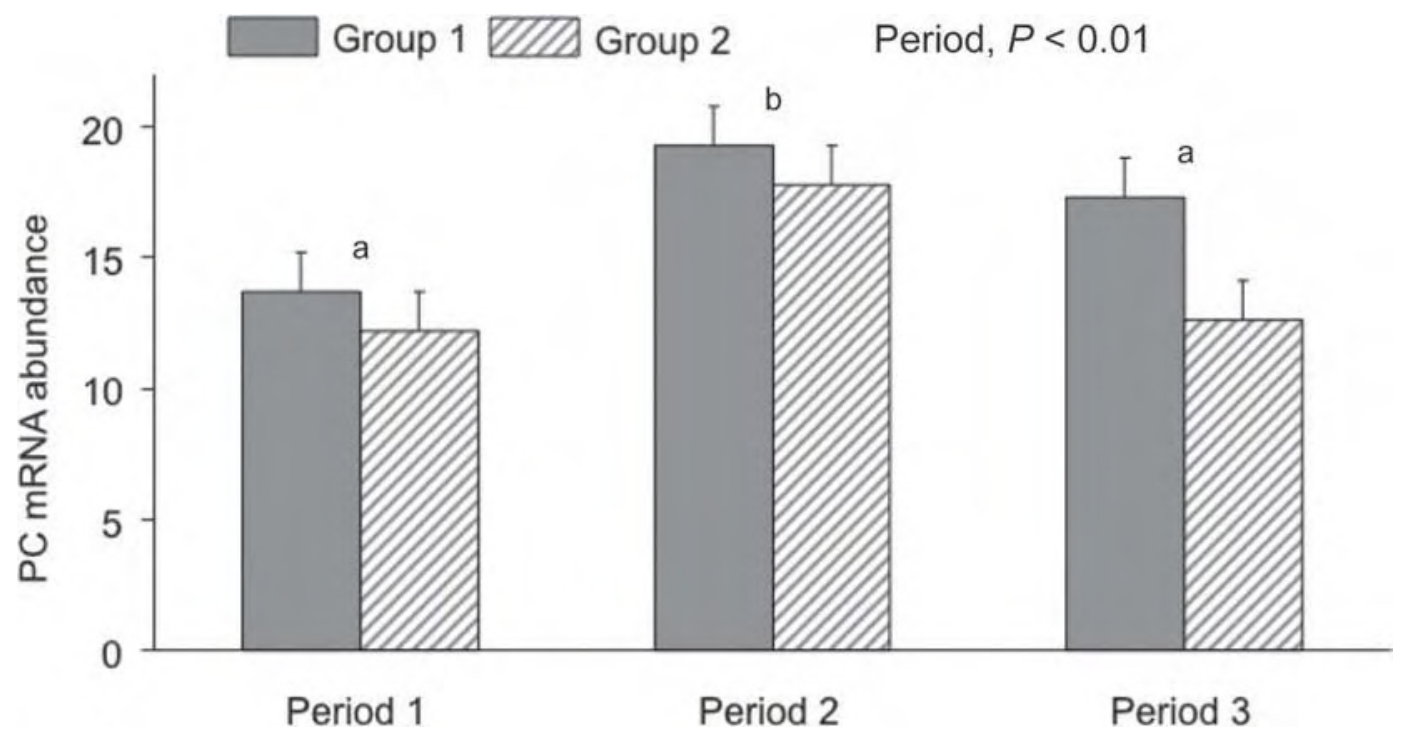

Figure 2. Effect of heat stress and plane of nutrition on bovine hepatic pyruvate carboxylase (PC) gene expression. Cows were separated into 2 groups based on pair feeding (group 1) or heat stress (group 2) treatment and studied during environmental conditions consisting of 3 periods. During period 1, each group was housed in thermal-neutral conditions and given ad libitum access to feed. During period 2, group 1 was pair fed (based on group 2 intake in period 2) and maintained in thermal-neutral conditions, whereas group 2 cows were maintained in heat stress conditions. During period 3, each group remained in conditions as described in period 2 and was administered recombinant bST on d 1 of period 3. Different letters denote period differences $(P<0.01)$.

effect as a similar change in PC gene expression was observed in PF counterparts. This idea is supported by previous work demonstrating the stimulatory effect of undernutrition or negative energy balance or a combination of the 2 on hepatic PC expression (Greenfield et al., 2000; Bradford and Allen, 2005; Velez and Donkin,
2005). Recent work, however, has shown that HS can increase PC gene expression in an in vitro bovine primary hepatocyte system (White et al., 2009). In this in vitro model, alteration in nutrient status is controlled and therefore indicates HS may directly regulate $\mathrm{PC}$ mRNA abundance. The possibility that HS might di-

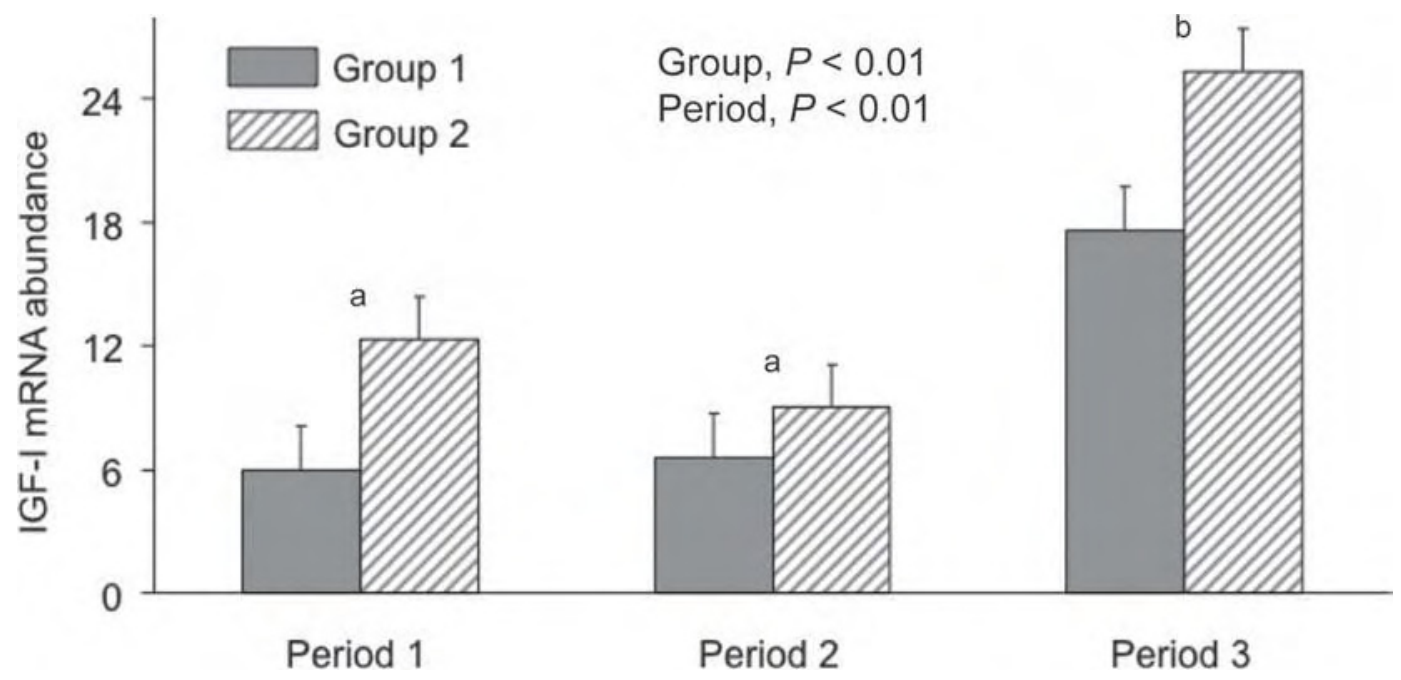

Figure 3. Effect of heat stress and plane of nutrition on bovine hepatic IGF-I gene expression. Cows were separated into 2 groups based on pair feeding (group 1) or heat stress (group 2) treatment and studied during environmental conditions consisting of 3 periods. During period 1, each group were housed in thermal-neutral conditions and given ad libitum access to feed. During period 2, group 1 was pair fed (based on group 2 intake in period 2) and maintained in thermal-neutral conditions, whereas group 2 cows were maintained in heat stress conditions. During period 3, each group remained in conditions as described in period 2 and was administered recombinant bST on d 1 of period 3. Different letters denote period differences $(P<0.01)$. 
rectly modify intrinsic properties of hepatocytes to elicit changes in PC gene expression warrants further study.

Heat-stressed dairy cattle appear to mobilize skeletal muscle (Kamiya et al., 2006; Shwartz et al., 2009) and do this to a greater extent than PF thermal-neutral controls (Wheelock et al., 2010). An increase in plasma lactate also is evident in HS cattle (Elsasser et al., 2009). Similar metabolic shifts occur in HS humans, and it is thought that this increases precursor (AA and lactate) supply for gluconeogenesis (Febbraio, 2001). Because $\mathrm{PC}$ is the rate-limiting enzyme responsible for shuttling AA (alanine) and lactate into the gluconeogenic pathway (Drackley et al., 2006), the increase in PC mRNA abundance we observe during HS is consistent with these observations. Surprisingly, administering rbST decreased PC gene expression in both groups during P3, but was most pronounced in the HS cows. The basis for this observation is unclear as administration of bST during HS could alter PC mRNA abundance directly or via indirect actions stemming from bST-directed changes in the systemic hormonal and metabolic milieu. Neither HS treatment nor bST administration during either treatment was sufficient to produce an effect on liver PCK mRNA abundance supporting the observations of Pershing et al. (2002) but not Velez and Donkin (2004) in their bST studies. In contrast, a reduced plane of nutrition produced a modest increase in PCK mRNA abundance, contradicting a previous report (Velez and Donkin, 2004). Thus, although rbST clearly increases hepatic glucose output, the molecular mechanism(s) remain(s) poorly defined.

The liver can become refractory to bST in terms of IGF-I production during periods of poor nutrition or disease (Bauman and Vernon, 1993; Donaghy and Baxter, 1996; Rhoads et al., 2007). Heat stress also appears to limit hepatic responsiveness to bST by reducing growth hormone receptor abundance (Rhoads et al., 2010). We tested this possibility and found a clear increase in hepatic IGF-I mRNA abundance during bST administration, irrespective of environmental condition (HS or PF), indicating that the liver is able to mount a GH response. Therefore, the lack of a positive effect by bST on gluconeogenic gene expression is unlikely to stem from reduced hepatic bST responsiveness. However, this study did not investigate intracellular signaling pathways, and it remains possible that the negative energy balance associated with heat stress and undernutrition may have caused differential regulation of $\mathrm{GH}$ signaling pathways, resulting in altered GH-dependent gluconeogenic activity.

\section{REFERENCES}

Bauman, D. E., and R. G. Vernon. 1993. Effects of exogenous bovine somatotropin on lactation. Annu. Rev. Nutr. 13:437-461.
Bradford, B. J., and M. S. Allen. 2005. Phlorizin administration increases hepatic gluconeogenic enzyme mRNA abundance but not feed intake in late-lactation dairy cows. J. Nutr. 135:2206-2211.

Donaghy, A. J., and R. C. Baxter. 1996. Insulin-like growth factor bioactivity and its modification in growth hormone resistant states. Baillieres Clin. Endocrinol. Metab. 10:421-446.

Drackley, J. K., S. S. Donkin, and C. K. Reynolds. 2006. Major advances in fundamental dairy cattle nutrition. J. Dairy Sci. 89:1324-1336.

Elsasser, T., R. Rhoads, S. Kahl, R. Collier, L. Baumgard, C. Li, and T. Caperna. 2009. Heat stress augments plasma tyrosine-nitrated proteins and lactate-to-pyruvate ratio after repeated endotoxin (LPS) challenge in steers. J. Anim. Sci. 89(E-Suppl. 2):9. (Abstr.)

Febbraio, M. A. 2001. Alterations in energy metabolism during exercise and heat stress. Sports Med. 31:47-59.

Greenfield, R. B., M. J. Cecava, and S. S. Donkin. 2000. Changes in mRNA expression for gluconeogenic enzymes in liver of dairy cattle during the transition to lactation. J. Dairy Sci. 83:1228-1236.

Kamiya, M., Y. Kamiya, M. Tanaka, T. Oki, Y. Nishiba, and S. Shioya. 2006. Effects of high ambient temperature and restricted feed intake on urinary and plasma 3-methylhistidine in lactating Holstein cows. Anim. Sci. J. 77:201-207.

Pershing, R. A., S. D. Moore, A. C. Dinges, W. W. Thatcher, and L. Badinga. 2002. Short communication: Hepatic gene expression for gluconeogenic enzymes in lactating dairy cows treated with bovine somatotropin. J. Dairy Sci. 85:504-506.

Rhoads, M. L., J. W. Kim, R. J. Collier, B. A. Crooker, Y. R. Boisclair, L. H. Baumgard, and R. P. Rhoads. 2010. Effects of heat stress and nutrition on lactating Holstein cows: II. Aspects of hepatic growth hormone responsiveness. J. Dairy Sci. 93:170-179.

Rhoads, M. L., R. P. Rhoads, M. J. VanBaale, R. J. Collier, B. A. Crooker, and L. H. Baumgard. 2009. Effects of heat stress and plane of nutrition on lactating Holstein cows: I. Production, metabolism and aspects of circulating somatotropin. J. Dairy Sci. 92:1986-1997.

Rhoads, R. P., J. W. Kim, B. J. Leury, L. H. Baumgard, N. Segoale, S. J. Frank, D. E. Bauman, and Y. R. Boisclair. 2004. Insulin increases the abundance of the growth hormone receptor in liver and adipose tissue of periparturient dairy cows. J. Nutr. 134:1020-1027.

Rhoads, R. P., J. W. Kim, M. E. Van Amburgh, R. A. Ehrhardt, S. J. Frank, and Y. R. Boisclair. 2007. Effect of nutrition on the growth hormone responsiveness of liver and adipose tissue in dairy cows. J. Endocrinol. 195:49-58.

Shwartz, G., M. L. Rhoads, K. A. Dawson, M. J. VanBaale, R. P. Rhoads, and L. H. Baumgard. 2009. Effects of a supplemental yeast culture on heat stressed lactating Holstein cows. J. Dairy Sci. 92:935-942.

St. Pierre, N. R., B. Cobanov, and G. Schnitkey. 2003. Economic losses from heat stress by U.S. livestock industries. J. Dairy Sci. 86:E52-E77.

Velez, J. C., and S. S. Donkin. 2004. Bovine somatotropin increases hepatic phosphoenolpyruvate carboxykinase mRNA in lactating dairy cows. J. Dairy Sci. 87:1325-1335.

Velez, J. C., and S. S. Donkin. 2005. Feed restriction induces pyruvate carboxylase but not phosphoenolpyruvate in dairy cows. J. Dairy Sci. 88:2938-2948.

Wheelock, J. B., A. J. La Noce, M. D. O'Brien, S. R. Sanders, R. J. Collier, L. H. Baumgard, and R. P. Rhoads. 2008. The effect of heat stress and exogenous bovine somatotropin on expression of genes associated with hepatic gluconeogenesis in lactating dairy cows. J. Dairy Sci. 91(E-Suppl. 1):455. (Abstr.)

Wheelock, J. B., R. P. Rhoads, M. J. VanBaale, S. R. Sanders, and L. H. Baumgard. 2010. Effects of heat stress on energetic metabolism in lactating Holstein cows. J. Dairy Sci. 93:644-655.

White, H. M., S. L. Koser, and S. S. Donkin. 2009. Regulation of bovine pyruvate carboxylase mRNA and promoter expression by heat stress. J. Dairy Sci. 92(E-Suppl. 1):139. (Abstr.) 